\title{
Comparison Of The Effects Of Glucose And Coffee Toward Blood Glucose Levels And Muscular Endurance After Eccentric Activity
}

\author{
Ahmad Ilham Habibi' ${ }^{1)}$, Ary Artanty ${ }^{2)}$, Afif Rusdiawan ${ }^{3)}$ \\ ${ }^{1,2,3}$ Pendidikan Jasmani Kesehatan dan Rekreasi \\ Fakultas Pendidikan Ilmu Ekskta dan Keolahragaan \\ IKIP Budi Utomo Malang, Jawa Timur Indonesia \\ Email : ${ }^{1}$ habibiilham44@gmail.com, ${ }^{2}$ aryartanty@budiutomomalang.ac.id, \\ Rusdiawan@gmail.com
}

\begin{abstract}
The study aims to know the effects of glucose and coffe on blood glucose levels and muscular endurance after eccentric activity. The reseach subjects of badminton athletes PB MBC Malang fell 27 male athletes. Design (Randomized group pretest and posttest disign) is the research design chosen for this study. Glucose given before students do eccentric sports with a dose of 10 grams $/ 70 \mathrm{~kg} \mathrm{BW}$, coffee given at a dose of 10grams $/ 70 \mathrm{~kg} B W$. Eccentrie activity done by pulling up 2 sets, 7 repettions and 30 seconds interval. Blood glucose measured using a glucometer 3 times, while a pust up test chosen to measure the strength and endurance of the arm muccels carried out for 1 minute. LSD test results some significant comparisons on blood glucose variables between the control group with glucose $p=0,013$, the control group with coffee $p=0,579$. The endurance variable showed significant comparison in the blood glucose variable in the control group and the glucose group with a value of $p=0,005$ and the control group with coffee giving of $p=0,026$ while in the glucose and coffee group no significant effect with a value of 0,485.
\end{abstract}

Keywords: Endurance, Glucose, Exercise, Coffee, Eccentric.

\section{PERBANDINGAN EFEK PEMBERIAN GLUKOSA DAN KOPI TERHADAP KADAR GLUKOSA DARAH DAN DAYA TAHAN OTOT SETELAH AKTIVITAS EKSENTRIK}

\author{
ABSTRAK
}

Penelitian ini bertujuan untuk melihat efek dari pemberian glukosa maupun kopi terhadap kadar glukosa darah dan daya tahan otot setelah aktivitas eksentrik. Subyek penelitian atlet bulutangkis PB MBC Malang berjumlah 27 atlet putra. Desain (Randomized group pre test and post test design) merupakan desain penelitian yang dipilih untuk penelitian ini. Glukosa diberikan sebelum atlet melakukan aktivitas olahraga eksentrik dengan dosis $75 \mathrm{gram} / 70 \mathrm{Kg}$ $\mathrm{BB}$, kopi diberikan dengan dosis $10 \mathrm{gram} / 70 \mathrm{Kg} \mathrm{BB}$. Aktivitas eksentrik dilakukan dengan pull up sebanyak 2 set, 7 kali repetisi dan 30 detik interval. Glukosa darah diukur menggunakan glukometer sebanyak 3 kali, sedangkan tes push up dipilih untuk mengukur kekuatan daya tahan otot lengan selama 1 menit. Hasil uji $L S D$ terdapat beberapa perbandingan yang signifikan pada variabel glukosa darah antara kelompok kontrol dengan pemberian glukosa $\mathrm{p}=0,013$, kelompok kontrol dengan pemberian kopi $\mathrm{p}=0,042$ sedangkan kelompok glukosa dan kopi tidak terdapat perbedaan signifikan $p=0,597$. Variabel daya tahan menunjukkan perbandingan yang signifikan pada variabel glukosa darah pada kelompok kontrol dan pemberian glukosa dengan nilai $\mathrm{p}=0,005$ dan kelompok kontrol dengan pemberian kopi dengan nilai $\mathrm{p}=0,026$ sedangkan pada kelompok glukosa dan kopi tidak terdapat perbedaan signifikan dengan nilai 0,485 .

Kata Kunci: Daya Tahan, Glukosa, Latihan, Kopi, Eksentrik

Info Artikel

Dikirim

Diterima

Dipublikasikan
12 November 2019

: 4 Mei 2020

: 11 Mei 2020
(C) 2020 IKIP BUDI UTOMO MALANG

P-ISSN 2613-9421

E-ISSN 2654-8003

\ Alamat korespondensi: habibiilham44@gmail.com 


\section{PENDAHULUAN}

Glukosa darah penting untuk aktivitas fisik, karena performa atlit dan daya tahan tubuh sangat dipengaruhi oleh glukosa darah, kadar glukosa darah seorang atlit menurun dapat mempengaruhi kinerja pada sel otot. Kebutuhan glukosa dalam tubuh dapat terpenuhi salah satunya dengan mengkomsumsi minuman yang mengandung karbohidrat cair seperti glukosa, akan tetapi minuman yang mengandung glukosa tidak langsung memberikan efek untuk meningkatkan kadar glukosa darah (R \& MG, 2015). Minuman olahraga yang mengandung glukosa bisa bermanfaat ganda, selain memberikan rasa manis glukosa juga bermanfaat untuk menambah tenaga mencegah hipoglikemia (turunya gula darah), mencegah lemas, dan menurunya kadar hormone stress dalam tubuh (Qin et al., 2017)

Selain pemberian glukosa, pemberian kopi juga dapat meningkatkan performa atlet. Hal ini mungkin disebabkan efek langsung kafein pada kontraksi otot selama aktivitas fisik. Kafein yang merupakan komponen kopi memiliki efek menggunakan lemak sebagai sumber energi dan peningkatan kadar kalsium sel otot, sehingga minuman yang mengandung kafein dapat mengurangi penggunaan glukosa dan mengurangi kelelahan.

Kafein juga dapat bermanfaat untuk merangsang otak (7,5-150 mg) sehingga aktifitas neural dalam otak dapat meningkat serta mengurangi kelelahan sehingga dapat menunda waktu tidur (Gurley, Steelman, \& Thomas, 2015). Kafein mempunyai efek ergogenik yang dapat meningkatkan peforma atlet, terutama untuk meningkatkan ketahanan aerobik dan meningkatkan kemampuan repetisi pada latihan otot (Nandatama, Rosidi, \& Gizi, 2017)

Kontraksi eksentrik ditandai dengan adanya perpanjangan pada otot dan tendon akibat dari gaya yang diberikan pada otot melebihi kekuatan otot itu sendiri. Selama proses tersebut, otot menyerap energy dari eksternal load sehingga kontraksi eksentrik ini sering disebut "negative work"(Hody, Croisier, Bury, Rogister, \& Leprince, 2019). Kontraksi eksentrik memiliki hubungan yang sangat erat dengan metabolisme otot terhadap pelepasan ion $\mathrm{Ca}^{2+}$ dari retikulum sarkoplasma. Saat terjadinya kontraksi eksentrik, maka jembatan silang protein miosin dan aktin akan saling menjauh sehingga menimbulkan pemanjangan sarkomer. Pemanjangan tersebut juga dapat menghasilkan tegangan pada 
sarkomer yang melibatkan protein aktin dan miosin (Bubbico, 2010). Aktivitas fisik dengan kontraksi eksentrik umunya digunakan untuk menurunkan kadar glukosa darah seperti penderita diabetes. Hal tersebut dikarenakan gaya yang diberikan ke otot melebihi kekuatan otot itu sendiri sehingga otot berkontraksi memanjang (Vogt \& Hoppeler, 2014).

Karena pemberian glukosa maupun kopi sama-sama dapat menunda kelelahan dengan meningkatkan kadar glukosa darah dan daya tahan, maka penulis perlu melakukan penelitian tentang perbandingan efek pemberian glukosa dan kopi terhadap kadar glukosa darah dan daya tahan otot setelah akttivitas eksentrik.

\section{METODE}

Dalam penelitian ini menggunakan jenis penelitian eksperimenal laboratoris, di mana desain penelitian yang diambil adalah jenis desain (Randomized group pre test and post test design).

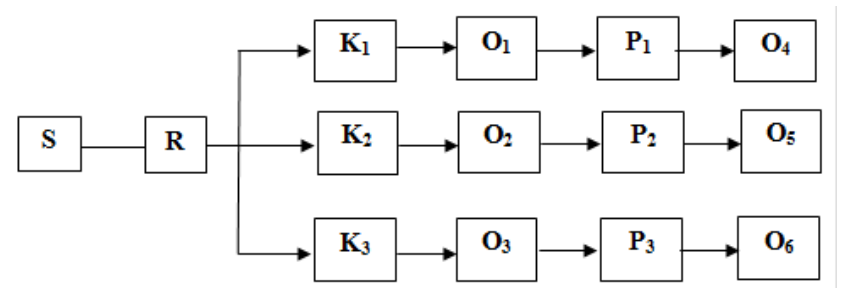

Gambar 1. Skema Rancangan Penelitian

Keterangan:

S : Sampel penelitian

$\mathrm{R}$ : Randomisasi

$\mathrm{K}_{1}$ : Kelompok kontrol (air mineral $150 \mathrm{ml}$ )

$\mathrm{K}_{2}$ : Kelompok pemberian glukosa $(75 \mathrm{gram} / 70 \mathrm{Kg} \mathrm{BB}+$ air mineral $)$

$\mathrm{K}_{3}$ : Kelompok pemberian kopi (10 gram/ $70 \mathrm{Kg} \mathrm{BB}+$ air mineral)

$\mathrm{O}_{1}$ : Pre test pada $\mathrm{K}_{1}$

$\mathrm{O}_{2}$ : Pre test pada $\mathrm{K}_{2}$

$\mathrm{O}_{3}$ : Pre test pada $\mathrm{K}_{2}$

$\mathrm{P}_{1}$ : Air mineral + aktivitas eksentrik

$\mathrm{P}_{2}$ : Glukosa + aktivitas eksentrik

$\mathrm{P}_{3}$ : Kopi + aktivitas eksentrik

$\mathrm{O}_{4}$ : Post test pada $\mathrm{K}_{1}$

$\mathrm{O}_{5}:$ Post test pada $\mathrm{K}_{2}$

$\mathrm{O}_{6}$ : Post test pada $\mathrm{K}_{3}$

Subyek penelitian menggunakan atlet putra PB MBC Malang usia 18-22 tahun dengan berat badan antara 55-70 $\mathrm{Kg}$, mempunyai IMT dan tekanan darah 
yang normal, tidak melakukan latihan eksentrik menjelang dan selama penelitian, tidak mengkonsumsi kafein maupun minum obat-obatan 1 minggu pra penelitian, dan memiliki aktivitas melakukan latihan resistance dengan lama latihan 6 bulan sebelumnya. Subyek penelitian seluruhnya dibagi secara acak kedalam 3 kelompok, yang masing-masing 9 orang per kelompok. Diantaranya kelompok kontrol $\left(\mathrm{K}_{1}\right)$, kelompok pemberian glukosa $\left(\mathrm{K}_{2}\right)$ dan kelompok pemberian kopi $\left(\mathrm{K}_{3}\right)$.

Prosedur penelitian pertama yaitu melakukan pemeriksaan kesehatan awal yakni dilakukan dengan wawancara mengenai aktifitas keseharian dan riwayat kesehatan, pemeriksaan fisik yaitu pemeriksaan tekanan darah, denyut jantung dan pengukuran indeks massa tubuh (IMT) subjek penelitian. Subjek penelitian diberikan penjelasan dan mengisi information for consent. Sebelum diambil datanya, subjek penelitian hanya diperbolehkan mengkonsumsi air mineral selama 8 jam. Langkah selanjutnya adalah melakukan pengukuran glukosa darah menggunakan alat glukometer merk accu chek performa dan push up untuk tes daya tahan otot dilakukan selama 1 menit. Setelah melakukan pre test, subjek penelitian diberikan air mineral $(150 \mathrm{ml})$ bagi kelompok kontrol, glukosa 75 gram/ $70 \mathrm{Kg}$ BB (Nugrahani, 2014). dan kopi 10 gram/70 Kg BB (Yustisiani, Andari, \& I. 2017) bagi kelompok perlakuan. Selanjutnya 1 jam setelah diberikan air mineral, glukosa maupun kopi, subjek penelitian diukur kembali glukosa darahnya (glukosa darah post prandial) kemudian melakukan latihan eksentrik berupa latihan pull up sebanyak 2 set, 7 repetisi dengan interval 30 detik (Pribadi, 2016). Segera setelah melakukan aktivitas eksentrik, subyek penelitian melakukan post test yaitu pengukuran glukosa darah post exercise dan tes push up untuk mengukur daya tahan.

Data yang didapatkan dari hasil penelitian kemudian dianalisis menggunakan bantuan software SPSS 20 dengan derajat signifikansi sebesar 5\%. Uji statistik yang digunakan yaitu uji deskriptif, uji homogenitas, uji normalitas, uji manova dan uji $L S D$. 


\section{HASIL DAN PEMBAHASAN}

\section{Statisik Deskriptif dan Uji Homogenitas}

Hasil penelitian yang dilakukan, diperoleh hasil variabel berat badan $(\mathrm{kg})$ tinggi badan $(\mathrm{cm})$, glukosa darah $(\mathrm{mg} / \mathrm{dL})$ dan daya tahan otot. Berikut ini adalah sebaran data berdasarkan rerata dan standart deviasi variabel berat badan, tinggi badan, kadar glukosa darah dan daya tahan otot masing - masing kelompok.

\section{Data berat badan dan tinggi badan}

Deskripsi uraian berat badan dan tinggi badan atlet dapat dilihat pada tabel 1 .

Tabel 1. Hasil Statistik Deskriptif Rerata Berat Badan dan Tinggi Badan dan Uji Homogenitas

\begin{tabular}{lllll}
\hline Variabel & Kontrol & Glukosa & Kopi & p (sig) \\
\hline Berat badan $(\mathrm{kg})$ & $61,56 \pm 4,27$ & $60,22 \pm 3,27$ & $61,56 \pm 4,72$ & 0,451 \\
Tinggi badan $(\mathrm{cm})$ & $168,33 \pm 3,04$ & $168,67 \pm 2,96$ & $166,44 \pm 6,17$ & 0,080
\end{tabular}

p>0,05 menunjukkan data variabel homogen

Berdasarkan tabel di atas data berat badan kelompok kontrol, glukosa dan kopi homogen dengan nilai $\mathrm{p}=0,451$, sedangkan data tinggi badan kelompok kontrol, glukosa dan kopi juga homogen dengan nilai $\mathrm{p}=0,080$.

\section{Data glukosa darah}

Deskripsi data glukosa darah dapat dilihat pada tabel 2.

Tabel 2. Hasil Statistik Deskriptif Rerata dan Uji Homogenitas Kadar Glukosa Darah

\begin{tabular}{lllll}
\hline \multirow{2}{*}{ Variabel } & \multicolumn{3}{c}{ Rerata \pm SD $(\mathrm{mg} / \mathrm{dL})$} & $\mathrm{p}(\mathrm{sig})$ \\
\cline { 2 - 4 } & Kontrol & Glukosa & Kopi & \\
\hline Pretes & $95,78 \pm 12,26$ & $91,44 \pm 15,87$ & $83,78 \pm 9,36$ & 0,177 \\
\hline Post test 1 & $95,89 \pm 12,17$ & $127,11 \pm 14,00$ & $137,89 \pm 16,09$ & 0,714 \\
\hline Post test 2 & $72,44 \pm 11,00$ & $100,89 \pm 10,83$ & $100,22 \pm 9,55$ & 0,942 \\
\hline
\end{tabular}

$\mathrm{p}>0,05$ menunjukkan data variabel homogeny

Uji homogenitas glukosa darah baik saat pre tes maupun post test 1 dan post test 2 setiap kelompok memiliki hasil yang signifikan. Hal ini dibuktikan dengan nilai pre test $(\mathrm{p}=0,177)$, post test $1(\mathrm{p}=0,714)$ dan post test $2(\mathrm{p}=$ 0,942). Sehingga dapat disimpulkan bahwa semua data glukosa darah bersifat homogen. Hasil uji deskriptif disajikan pada gambar 2. 


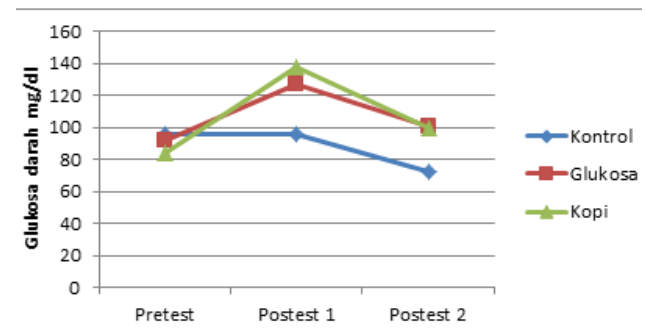

Gambar 2. Diagram Garis Glukosa Darah Kelompok Kontrol, Glukosa dan Kopi

Gambar di atas didapatkan hasil kadar glukosa darah yang hampir sama pada kelompok kontrol sebesar 95,89 \pm 12,17 mg/dL, meningkat pada kelompok glukosa sebesar 127,11 \pm 14,00 mg/dL dan kelompok kopi sebesar 137,89 \pm 16,09 $\mathrm{mg} / \mathrm{dL}$. Setelah post test 1 dilakukan pemulihan dan dilakukan lagi post test 2 dan didapatkan hasil yang masih menurun pada semua kelompok yakni kelompok kontrol sebesar 72,44 \pm 11,00 mg/dL pada kelompok glukosa sebesar 100,89 \pm 10,83 mg/dL dan kelompok kopi sebesar 100,22 \pm 9,55 mg/dL.

\section{Data daya tahan otot lengan}

Deskripsi daya tahan otot lengan dapat dilihat pada tabel 3.

Tabel 3. Hasil Statistik Deskriptif dan Homogenitas Daya Tahan Otot Lengan

\begin{tabular}{lllll}
\hline Variabel & Kontrol & Glukosa & Kopi & p (sig) \\
\hline $\begin{array}{l}\text { Daya tahan otot } \\
\text { lengan }\end{array}$ & $29,22 \pm 4,12$ & $35,00 \pm 3,43$ & $33,67 \pm 4,36$ & 0,690 \\
\hline p $>0,05$ menunjukkan data variabel homogeny & & \\
\hline
\end{tabular}

Uji homogenitas daya tahan otot lengan pada semua kelompok menunjukkan hasil yang signifikan. Hal ini dibuktikan dengan nilai $\mathrm{p}=0,690$ Sehingga dapat disimpulkan bahwa semua data glukosa darah bersifat homogen.

\section{Uji Normalitas}

Hasil uji normalitas data dengan menggunakan uji Shapiro wilk dapat dilihat pada tabel 4.

Tabel 4. Hasil Uji Normalitas Variabel

\begin{tabular}{|c|c|c|c|c|c|c|}
\hline \multirow{2}{*}{$\begin{array}{l}\text { Variabe } \\
1\end{array}$} & \multicolumn{6}{|c|}{ Kadar glukosa darah (mg/dL) } \\
\hline & Pre & Post 1 & Post 2 & $\begin{array}{l}\text { Delta } 1 \\
\text { (pre-post1) }\end{array}$ & $\begin{array}{l}\text { Delta } 2 \\
\text { (pre-post } 2 \text { ) }\end{array}$ & Otot Lengan \\
\hline Kontrol & 0,101 & 0,124 & 0,151 & 0,308 & 0,706 & 0,715 \\
\hline Glukosa & 0,168 & 0,685 & 0,973 & 0,625 & 0,110 & 0,962 \\
\hline Kopi & 0,291 & 0,760 & 0,596 & 0,874 & 0,389 & 0,430 \\
\hline
\end{tabular}


Hasil uji normalitas data glukosa darah dan daya tahan otot lengan didapatkan bahwa semua data berdistribusi normal $\mathrm{p}>0,05$, baik kelompok kelompok kontrol, kelompok glukosa dan kelompok kopi.

\section{Uji Manova}

Hasil uji manova dapat dilihat pada tabel 5.

Tabel 5. Hasil Test of Between-Subjects Effects

\begin{tabular}{ll}
\hline Variabel & $\mathbf{P}($ sig) \\
\hline Kadar glukosa darah & 0,031 \\
Daya tahan otot lengan & 0,013 \\
\hline
\end{tabular}

$\mathrm{P}<0,05$ terdapat perbedaan yang bermakna

Hasil analisis tersebut menunjukkan bahwa pemberian glukosa maupun kopi secara bermakna mempengaruhi kadar glukosa darah yang ditunjukkan dengan nilai $\mathrm{p}=$ 0,031 pada kelompok kontrol, glukosa dan kopi. Selain itu juga secara bermakna pemulihan mempengaruhi kadar glukosa darah yang ditunjukkan dengan nilai $\mathrm{p}=0,013$ pada kelompok kontrol, glukosa dan kopi.

\section{Uji Post Hoc Test}

Tahapan selanjutnya dalam penelitian ini adalah melakukan uji post hoc test menggunakan uji $L S D$ pada variabel glukosa darah dan daya tahan. Hasil uji post hoc test bisa dilihat pada tabel 6.

Tabel 6. Hasil Uji Post Hoc Test Variabel Glukosa Darah Dan Daya Tahan Otot

\begin{tabular}{llll}
\hline Variabel & Kelompok & & $\mathbf{P}(\mathbf{s i g})$ \\
\hline Glukosa darah & Control & Glukosa & 0,013 \\
\cline { 2 - 4 } & & Kopi & 0,042 \\
\cline { 2 - 4 } & Glukosa & Kopi & 0,597 \\
\hline Daya Tahan Otot & Control & Glukosa & 0,005 \\
\cline { 2 - 4 } & & Kopi & 0,026 \\
\cline { 2 - 3 } & Glukosa & Kopi & 0,485 \\
\hline & $\mathrm{P}<0,05$ terdapat perbedaan yang bermakna
\end{tabular}

Data uji LSD diatas pada variabel glukosa darah menunjukkan ada perbedaan yang bermakna antara kelompok kontrol dengan kelompok glukosa $(\mathrm{p}=0,013)$ dan kelompok kontrol dengan kelompok kopi $(\mathrm{p}=0,042)$. Sedangkan pada kelompok glukosa dengan kelompok kopi menunjukkan tidak terdapat perbedaan yang bermakna $(\mathrm{p}=0,597)$.

Sedangkan uji LSD pada variabel daya tahan otot menunjukkan adanya perbedaan yang bermakna antara kelompok kontrol dengan kelompok glukosa 
$(\mathrm{p}=0,005)$ dan kelompok kontrol dengan kelompok kopi $(\mathrm{p}=0,026)$. Namun pada kelompok glukosa dengan kelompok kopi menunjukkan tidak terdapat perbedaan yang bermakna $(\mathrm{p}=0,485)$.

\section{Pengaruh pemberian glukosa terhadap kadar glukosa darah setelah aktivitas eksentrik}

Pada keadaan postprandial, insulin dilepas pada 2 fase yaitu 1) singkat, pelepasan yang sedikit pada saat makan untuk menurunkan peningkatan glukosa darah postprandial, 2) insulin dilepas langsung dengan jumlah proporsional dengan terjadinya peningkatan kadar glukosa darah, sehingga terjadi glikogenesis antara lain di hati dan di otot sehingga terjadi peningkatan uptake glukosa untuk ditumpuk sebagai glikogen. Karena aktivitas eksentrik sesaat dapat meningkatkan kadar GLUT-4 otot (Adelia, Bambang, \& Arifa, 2017).

Sesuai dengan teori diatas, kadar glukosa darah postprandial (GDPP) mengalami kenaikan pada kelompok glukosa setelah diberi glukosa secara oral. Glukosa darah yang tinggi ini akan digunakan otot sebagai energi siap pakai dan sebagian disimpan sebagai glikogen seperti penjelasan oleh Heru Syarli Lesmana dan Endang Pati Broto, glukosa yang dialirkan melalui darah adalah sumber energi utama untuk sel-sel tubuh (Lesmana \& Broto, 2019).

Kontraksi eksentrik terjadi saat gaya beban lebih besar dari pada gaya otot dan ditandai dengan pemanjangan otot (Adelia et al., 2017). Ketika terjadi kontraksi eksentrik, jembatan silang protein miosin dan aktin saling menjauh sehingga terjadi pemanjangan sarkomer. Pemanjangan ini juga menghasilkan tegangan pada sarkomer yang melibatkan protein aktin dan miosin. Kedua proses fisiologi kontraksi eksentrik ini yang akan memberikan stimulasi pada transporter glukosa fasilitatif sel otot, sehingga dapat meningkatkan ambilan glukosa darah otot (Bubbico, 2010).

Jadi, Glukosa darah dan glikogen yang mengalami penurunan akibat aktivitas eksentrik akan dipertahankan karena glukosa darah yang tinggi sebelum melakukan aktivitas eksentrik, sehingga penurunan kadar glukosa darah dan penggunaan glikogen rendah.

\section{Pengaruh pemberian glukosa terhadap daya tahan otot setelah aktivitas eksentrik}


Konsentrasi glukosa darah yang rendah akibat aktivitas eksentrik akan menurunkan daya tahan otot sehingga performa menurun (Rusdiawan \& Taufikkurrachman, 2020). Pemberian glukosa akan meningkatkan kadar glukosa darah sehingga konsentrasi glukosa darah sebagai energi meningkat. Karena peningkatan cadangan energy inilah maka daya tahan otot akan lebih baik (Habibi \& Artanty, 2019)

Berdasarkan analisa data terhadap variabel daya tahan otot setelah aktivitas eksentrik pada kelompok pemberian glukosa, di dapatkan hasil rerata daya tahan

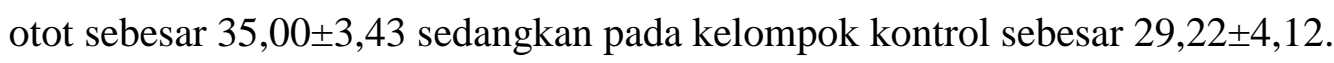

Selanjutnya hasil uji $L S D$ antara kelompok glukosa dan kontrol juga didapatkan nilai yang signifikan $(\mathrm{p}=0,005)$ pada variabel daya tahan otot. Hal ini menunjukkan bahwa terdapat perbedaan yang bermakna daya tahan otot setelah aktivitas eksentrik antara kelompok kontrol dan kelompok glukosa. memproduksi konsentrasi glikogen otot selama prosedur loading karbohidrat sehingga mencegah atau menunda kelelahan akibat latihan yang panjang.

Jadi, pemberian glukosa dapat menunda kelelahan karena sumber energi yang tinggi (glukosa darah) sehingga daya tahan otot lebih baik setelah melakukan aktivitas eksentrik.

\section{Pengaruh pemberian kopi terhadap kadar glukosa darah setelah aktivitas eksentrik}

Secara teoritis, kafein yang merupakan komponen utama kopi memang memiliki efek terhadap otot manusia melalui mekanisme utilisasi lemak menjadi energi dan peningkatan kadar kalsium sel otot, sehingga kafein dapat meningkatkan performa otot dan menghambat terjadinya kelelahan otot (Nandatama et al., 2017). Dari analisa data terhadap variabel glukosa darah didapatkan hasil rerata glukosa pretest kelompok kontrol sebesar 95,78 $\pm 12,25$

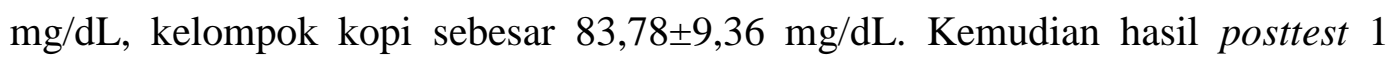
didapatkan rerata yang hampir sama pada kelompok kontrol sebesar 95,89 $\pm 12,17$

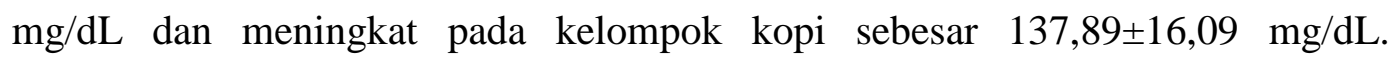
Selanjutnya setelah aktivitas eksentrik, hasil posttest 2 didapatkan rerata yang menurun pada kedua kelompok yakni kelompok kontrol sebesar 72,44 $\pm 11,00$ $\mathrm{mg} / \mathrm{dL}$ pada kelompok kopi sebesar 100,22 $\pm 9,55 \mathrm{mg} / \mathrm{dL}$. Dari hasil tersebut 
kemudian dicari selisih kadar glukosa darah saat posttest 1-postest 2 pada kedua kelompok. Selanjutnya dilakukan uji LSD antara kelompok kopi dan kontrol sehingga menghasilkan nilai yang signifikan $(\mathrm{p}=0,042)$ pada variabel glukosa darah. Hal ini menunjukkan bahwa terdapat perbedaan yang bermakna kadar glukosa darah setelah aktivitas eksentrik antara kelompok kontrol dan kelompok kopi.

Kafein juga dapat meningkatkan kadar glukosa darah dan menurunkan sensitifitas terhadap insulin (Swastika, 2013). Hal tersebut karena meningkatnya proses glikogenolisis di hepar dan otot rangka akibat pelepasan katekolamin.

Dari penjelasan teori diatas dapat diambil kesimpulan bahwa pemberian kafein dapat meningkatkan kadar glukosa darah melalui glikogenolisis dan glukoneogenesis pada hepar dan penurunan penggunaan glikogen otot melalui tingginya asam lemak bebas dalam plasma sehingga kadar glukosa darah dan cadangan glikogen otot dipertahankan agar tidak mengalami penurunan yang tinggi akibat aktivitas eksentrik.

\section{Pengaruh pemberian kopi terhadap daya tahan otot setelah aktivitas eksentrik}

Berdasarkan hasil penelitian dan analisa data terhadap variabel daya tahan otot setelah aktivitas eksentrik pada kelompok pemberian kopi di dapatkan hasil rerata daya tahan otot sebesar $33,67 \pm 4,36$ sedangkan pada kelompok kontrol sebesar 29,22 $\pm 4,12$

Selanjutnya hasil uji $L S D$ antara kelompok kopi dan kontrol juga didapatkan nilai yang signifikan $(\mathrm{p}=0,026)$ pada variabel daya tahan otot. Hal ini menunjukkan bahwa terdapat perbedaan yang bermakna daya tahan otot setelah aktivitas eksentrik antara kelompok kontrol dan kelompok kopi.

Menurut The International Society of Sport Nutrition, mengonsumsi minuman yang mengandung kafein 60 menit sebelum olahraga dapat meningkatkan ketajaman, kewaspadaan dan daya tahan otot (Gurley et al., 2015). Kafein mempunyai efek ergogenik yang dapat meningkatkan peforma atlet, terutama untuk meningkatkan ketahanan aerobik dan meningkatkan kemampuan repetisi pada latihan (Ayuso, 2019). 
Jadi, pemberian kopi dapat menunda kelelahan akibat aktivitas eksentrik dengan daya tahan otot yang baik karena kandungan kafein dalam kopi yang meningkatkan sumber energi glukosa darah dan glikogen otot dan hepar.

\section{Perbandingan pengaruh pemberian glukosa dan kopi terhadap kadar glukosa darah setelah aktivitas eksentrik}

Lukman khakim dalam penelitiannya menyatakan bahwa terdapat perbedaan yang bermakna efek kopi dapat mengurangi penurunan glukosa darah yang terlalu besar pada saat melakukan aktivitas fisik maupun segera setelah melakukan aktifitas fisik (Khakim, 2015). Berdasarkan hasil penelitian dan analisa data terhadap variabel glukosa darah didapatkan hasil rerata glukosa pretest kelompok glukosa sebesar 91,44 $\pm 15,87 \mathrm{mg} / \mathrm{dL}$, kelompok kopi sebesar $83,78 \pm 9,36 \mathrm{mg} / \mathrm{dL}$. Kemudian hasil posttest 1 didapatkan rerata yang sama-sama meningkat pada kedua kelompok yakni pada kelompok kontrol sebesar

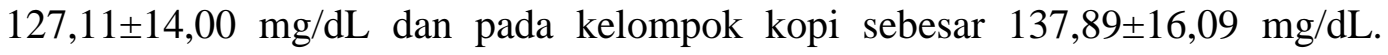
Selanjutnya setelah aktivitas eksentrik, hasil posttest 2 didapatkan rerata yang menurun pada kedua kelompok yakni kelompok glukosa sebesar 100,89 $\pm 10,83$ $\mathrm{mg} / \mathrm{dL}$ pada kelompok kopi sebesar 100,22 $\pm 9,55 \mathrm{mg} / \mathrm{dL}$. Dari hasil tersebut kemudian dicari selisih kadar glukosa darah saat posttest 1-postest 2 pada kedua kelompok. Selanjutnya dilakukan uji LSD antara kelompok glukosa dan kopi dan didapatkan nilai yang tidak signifikan $(\mathrm{p}=0,597)$ pada variabel glukosa darah. Hal ini menunjukkan bahwa tidak terdapat perbedaan yang bermakna kadar glukosa darah setelah aktivitas eksentrik antara kelompok glukosa dan kelompok kopi.

Pemberian kopi yang mengandung kafein dan pemberian glukosa dapat meningkatkan kadar glukosa darah (Swastika, 2013). Efek kafein dalam kopi mencapai puncak pada 60 menit setelah konsumsi (Gurley et al., 2015). Hal ini berarti sama pada efek puncak dengan pemberian glukosa sehingga hal tersebut yang memungkinkan tidak terdapat perbedaan secara bermakna pada kelompok glukosa dan kelompok kopi dalam halkadar glukosa darah.

Perbandingan pengaruh pemberian glukosa dan kopi terhadap daya tahan otot setelah aktivitas eksentrik

Berdasarkan hasil penelitian dan analisa data terhadap variabel daya tahan otot setelah aktivitas eksentrik pada kelompok pemberian kopi di dapatkan hasil 
rerata daya tahan otot sebesar $33,67 \pm 4,36$ sedangkan pada kelompok glukosa sebesar 35,00 $\pm 3,43$ (lihat table 3 dan gambar 3). Dari hasil tersebut dapat diketahui bahwa daya tahan otot setelah aktivitas eksentrik untuk kelompok pemberian glukosa lebih tinggi dari pada kelompok kopi. Namun hasil uji LSD antara kelompok glukosa dan kopi didapatkan nilai yang tidak signifikan $(\mathrm{p}=$ $0,485)$ pada variabel daya tahan otot. Hal ini menunjukkan bahwa tidak terdapat perbedaan yang bermakna daya tahan otot setelah aktivitas eksentrik antara kelompok kontrol dan kelompok kopi.

Kemampuan daya tahan otot pemberian glukosa maupun kopi sama-sama bergantung pada kadar glukosa darah dan cadangan glikogen otot. Pemberian glukosa dapat meningkatkan kadar glukosa darah dan sintesis glikogen sehingga cadangan energy meningkat dan dapat menunda kelelahan.

Pemberian kopi dapat meningkatkan oksidasi lemak dan menghemat glikogen sehingga dapat menunda waktu kelelahan. Hal tersebut akibat dari efek kafein yang terkandung dalam kopi.

\section{SIMPULAN}

1. Terdapat beberapa perbedaan yang sangat signifikan antara kelompok kontrol dan kelompok pemberian glukosa pada variabel glukosa darah dengan nilai $\mathrm{p}=$ 0,013 dan pada variabel daya tahan dengan nilai $\mathrm{p}=0,005$. Hal tersebut berarti pemberian glukosa dapat meningkatkan glukosa darah dan daya tahan otot setelah aktivitas eksentrik.

2. Terdapat perbedaan yang signifikan antara kelompok kontrol dengan kelompok pemberian kopi pada variabel glukosa darah dengan nilai $\mathrm{p}=0,042$ dan pada variabel daya tahan dengan nilai $\mathrm{p}=0,026$. Hal tersebut berarti pemberian kopi dapat meningkatkan glukosa darah dan daya tahan otot setelah aktivitas eksentrik.

3. Tidak terdapat perbedaan kadar glukosa darah dan daya tahan otot pada kelompok pemberian glukosa dan kopi. Hal ini dibuktikan dengan nilai $\mathrm{p}=$ 0,597 pada variabel glukosa darah dan nilai $\mathrm{p}=0,485$ pada variabel daya tahan otot. 


\section{DAFTAR PUSTAKA}

Adelia, H., Bambang, P., \& Arifa, M. (2017). Pengaruh Aktivitas Eksentrik terhadap Kadar Glucose Transporter Tipe 4 pada Otot Gastrocnemius Mencit Diabetes Melitus yang Diinduksi Streptozotocin. Journal of Agromedicine and Medical Sciences, 3(3), 39-43.

Mielgo-Ayuso, J., Marques-Jiménez, D., Refoyo, I., Del Coso, J., León-Guereño, P., \& Calleja-González, J. (2019). Effect of Caffeine Supplementation on Sports Performance Based on Differences Between Sexes: A Systematic Review. Nutrients, 11(10), 2313.

Bubbico, A. and L. K. (2010). Eccentric Exercise. Retrieved October 29, 2019, from https://www.unm.edu/ lkravitz/Article folder/eccentricUNM.html

Gurley, B. J., Steelman, S. C., \& Thomas, S. L. (2015). Multi-Ingredient, Caffeine-Containing Dietary Supplements: History, Safety, And Efficacy. Clinical therapeutics, 37(2), 275-301.

Habibi, A. I., \& Artanty, A. (2019, October). Perbandingan Kemampuan Daya Tahan Otot Lengan Setelah Aktivitas Eksentrik Dengan Mengkonsusmsi Glukosa Dan Kopi. In Prosiding Seminar Nasional Iptek Olahraga (Senalog) (Vol. 2, No. 1).

Hody, S., Croisier, J. L., Bury, T., Rogister, B., \& Leprince, P. (2019). Eccentric Muscle Contractions: Risks And Benefits. Frontiers In Physiology, 10, 536.

Khakim, L. (2016). Efek Pemberian Kopi Terhadap Glukosa Darah Dan Laktat Darah Selama Dan Sesudah Aktifitas Fisik Submaksimal. Jurnal Sport Science, 4(3), 162-165.

Lesmana, H. S., \& Broto, E. P. (2018). Profil Glukosa Darah Sebelum, Setelah Latihan Fisik Submaksimal dan Selelah Fase Pemulihan Pada Mahasiswa FIK UNP. Media Ilmu Keolahragaan Indonesia, 8(2), 44-48.

Nandatama, S. R., Rosidi, A., \& Ulvie, Y. N. S. (2017). Minuman Kopi (Coffea) Terhadap Kekuatan Otot dan Ketahanan Otot Atlet Sepak Bola Usia Remaja di SSB PERSISAC. Jurnal Gizi, 6(1).

Nugrahani, S. S. (2013). Analisis Perbandingan Efektifitas Ekstrak Akar, Batang, dan Daun Herba Meniran dalam Menurunkan Kadar Glukosa Darah Mencit. Unnes Journal of Public Health, 2(1).

Pribadi, H. P. (2016). Studi Komparasi Kadar Skeletal Muscle Troponin I (Stni) Serum Dan Score Of Soreness Antara Recovery Aktif Dan Recovery Pasif Setelah Aktivitas Fisik Eksentrik (Doctoral dissertation, Universitas Airlangga).

Qin, L., Wang, Q. R., Fang, Z. L., Wang, T., Yu, A. Q., Zhou, Y. J., ... \& Yi, M. Q. (2017). Effects of Three Commercially Available Sports Drinks on Substrate Metabolism and Subsequent Endurance Performance in a Postprandial State. Nutrients, 9(4), 377. 
Roscamp, R., \& Santos, M. G. (2015). Effects of carbohydrates supplementation and physical exercise. Journal of Nutrition and Health Sciences, 2(3), 303.

Rusdiawan, A., \& Taufikkurrachman, T. (2019). Effect of Glutamine Supplement Administration on the Reduction of Muscular Fatigue Post-Eccentric Exercise. Folia Medica Indonesiana, 55(4), 275-279.

Swastika, K. D. (2012). Efek Kopi terhadap Kadar Gula Darah Post Prandial pada Mahasiswa Semester VII Fakultas Kedokteran USU Tahun 2012.

Vogt, M., \& Hoppeler, H. H. (2014). Eccentric exercise: mechanisms and effects when used as training regime or training adjunct. Journal of applied Physiology, 116(11), 1446-1454.

Yustisiani, A., \& Andari, D. (2017). Pengaruh Pemberian Kopi Terhadap Penurunan Kadar Glukosa Darah Pada Tikus Putih Strain Wistar Diabetes Mellitus Tipe 2. Saintika Medika: Jurnal Ilmu Kesehatan dan Kedokteran Keluarga, 9(1), 38-45. 